\title{
Skeletal Alterations Associated with the Use of Bonded Rapid Maxillary Expansion Appliance
}

\author{
Moara DE ROSSI ${ }^{1}$ \\ Andiara DE ROSSI ${ }^{1}$ \\ Jorge ABRÃO ${ }^{2}$ \\ ${ }^{1}$ Department of Pediatric Clinics, Preventive and Community Dentistry, Ribeirão Preto Dental School, \\ USP - University of São Paulo, Ribeirão Preto, SP, Brazil \\ ${ }^{2}$ Department of Pediatric Dentistry and Orthodontics, Dental School, \\ USP - University of São Paulo, São Paulo, SP, Brazil
}

\begin{abstract}
Bonded maxillary expansion appliances have been suggested to control increases in the vertical dimension of the face after rapid maxillary expansion (RME). However, there is still no consensus in the literature about its real skeletal effects. The purpose of this prospective study was to evaluate, longitudinally, the vertical and sagittal cephalometric alterations after RME performed with bonded maxillary expansion appliance. The sample consisted of 26 children, with a mean age of 8.7 years (range: 6.9-10.9 years), with posterior skeletal crossbite and indication for RME. After maxillary expansion, the bonded appliance was used as a fixed retention for 3.4 months, being replaced by a removable retention subsequently. The cephalometric study was performed onto lateral radiographs, taken before treatment was started, and again 6.3 months after removing the bonded appliance. Intra-group comparison was made using paired $t$ test. The results showed that there were no significant sagittal skeletal changes at the end of treatment. There was a small vertical skeletal increase in five of the eleven evaluated cephalometric measures. The maxilla displaced downward, but it did not modify the facial growth patterns or the direction of the mandible growth. Under the specific conditions of this research, it may be concluded that RME with acrylic bonded maxillary expansion appliance did promote signifciant vertical or sagittal cephalometric alterations. The vertical changes found with the use of the bonded appliance were small and probably transitory, similar to those occurred with the use of banded expansion appliances.
\end{abstract}

Key Words: orthodontic, palatal expansion technique, cephalometry.

\section{INTRODUCTION}

Posterior crossbite is a transversal malocclusion that establishes early, does not present self-correction and compromises aesthetics, occlusal stability and the normal oral functions. As such, to favor the normal growth and development of the craniofacial skeleton and the correct function of the stomatognathic system, treatment must be started as soon as the malocclusion is detected and the child is able to cooperate with the treatment (1). In cases of posterior crossbite of skeletal origin, where the transversal relation is compromised by the atresia of the maxillary bone, tooth movement in an attempt of correcting the skeletal deficiency leads invariably to recurrence. When maxillary narrowing is diagnosed, the treatment of choice should be rapid maxillary expansion (RME), which uses fixed maxillary expansion appliances to increase the maxillary width and dental arc perimeter by separating the midpalatal suture (2).

In addition to opening the midpalatal suture, some authors (3-5) have reported that short-term RME with conventional appliances (Haas and Hyrax models) promotes the anterior and inferior dislocation of the maxilla, inclination of the alveolar process, extrusion and buccal inclination of the posterior teeth, with a consequent posterior-inferior rotation of the mandible. Awareness of these effects motivated researchers to develop other types of appliances. Cohen and Silverman (6) described the use of bonded maxillary expansion appliance aiming at the possible intrusion of the posterior mandibular teeth, favoring treatment for patients with an exaggerated inclination of the mandibular plane. While Haas and Hyrax type appliances are banded to posterior teeth, the bonded rapid maxillary expansion appliance

Correspondence: Dra. Moara De Rossi, Departamento de Clínica Infantil, Odontologia Preventiva e Social, Faculdade de Odontologia de Ribeirão Preto, FORP-USP, Avenida do Café S/N, 14040-904 Ribeirão Preto, SP, Brasil. Tel.: +55-16-3602-3995. Fax: +55-16-3633-0990 e-mail: moderossi@yahoo.com.br 
is bonded to maxillary posterior teeth by a full acrylic surface coverage that encloses all occlusal surfaces. Different design bonded rapid maxillary expansion appliances were then proposed by other authors. Their common belief was that controlling the anteriorinferior facial height could inhibit alveolar growth and eruption of the posterior teeth, lower axial inclination and extrusion of the encapsulated teeth when compared with what occurs with conventional appliances (7-9).

However, the long-term (more than 3 months after expansion) RME effects in the vertical and sagittal axis are not well establish (10), especially when using the bonded maxillary expansion appliance (11). Could the use of bonded expansion appliance control the vertical dimension of the face or decrease the mandibular inclination even some months after the appliance removal? The clinical decision about the type of appliance to be used in each patient must be supported by scientific founds, especially those from longitudinal clinical study. Thus, the purpose of this prospective research was to evaluate the cephalometric anteroposterior and vertical effects associated with RME with bonded maxillary expansion appliance, at least 6 months after appliance removal. The results of this research provide useful data to help the clinicians about the choice or not of this appliance to control secondary effects of RME.

\section{MATERIAL AND METHODS}

\section{Sample Selection}

This prospective longitudinal study was approved by the University Ethics Committee (Protocol number 2003.1.1067.58.8). Children who sought treatment at the Preventive Orthodontic Clinic of the Ribeirão Preto Dental School, University of São Paulo within a 1-year period were screened as eligible participants. Twentysix children (14 females and 12 males) with mean age 8.7 years (range: 6.9-10.9 years), no race or social class distinctions, presenting maxillary narrowing and posterior crossbite, either unilateral or bilateral, with an indication for maxillary disjunction, were selected.

The following conditions were considered as inclusion criteria: early mixed dentition; presence of posterior crossbite combined with maxillary narrowing; presence of maxillary and mandibular first molars erupted and in occlusion; absence of cavited lesions; and good oral hygiene. Exclusion criteria were: presence of systemic or local disorders that could compromise the craniofacial growth or the performance of rapid maxillary expansion, such as neurologic disorders and cerebral palsy; early loss of primary or permanent teeth; any type of previous orthodontic treatment.

\section{Rapid Maxillary Expansion}

RME was performed with the acrylic bonded maxillary expansion appliance, similar to the one described by McNamara Jr. and Brudon (7), fabricated with clear acrylic resin covering the posterior teeth (Jet; Artigos Odontológicos Clássico Ltda., São Paulo, SP, Brazil) and a screw for palatal disjunction (split screw, 9 mm, reference code 65.05.011; Dental Morelli, Sorocaba, SP, Brazil), placed over the palatal raphe, about $2 \mathrm{~mm}$ far from the palate, and between the primary second molars (Fig. 1). The appliance was adjusted in the patient's mouth so as to obtain the largest possible number of occlusal contacts, bilaterally, and it was fixed with a resin-based dual-cure adhesive cement (Rely X; 3M ESPE, St. Paul, MN, USA).

One week after the appliance had been installed, the parents/guardians were instructed to perform onequarter turn activations of the screw, every $12 \mathrm{~h}$, at home. When the crossbite had been overcorrected, i.e., when the occlusal inclines on the palatal cusps of the upper molars occlude with the occlusal inclines of the buccal cusps of the lower molars, the screw of the appliance was immobilized with acrylic resin (Jet; Clássicos Produtos Odontológicos Ltda., São Paulo, SP, Brazil).

At the end of the activations, an occlusal radiograph was taken to confirm midpalatal suture opening. Patients remained with the appliance as a fixed

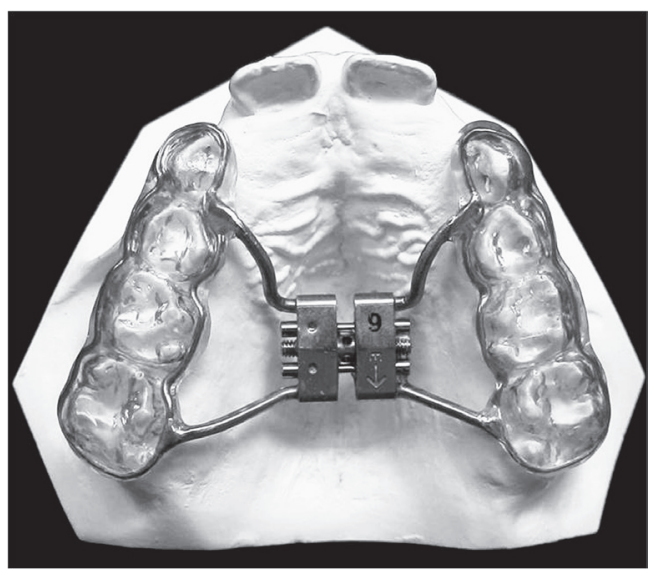

Figure 1. Bonded rapid maxillary appliance used in the study. 
retention for 3.4 months on average (varying from 3.2 to 4.1 months). After this period, a new occlusal radiograph was obtained to confirm the new bone formation in the

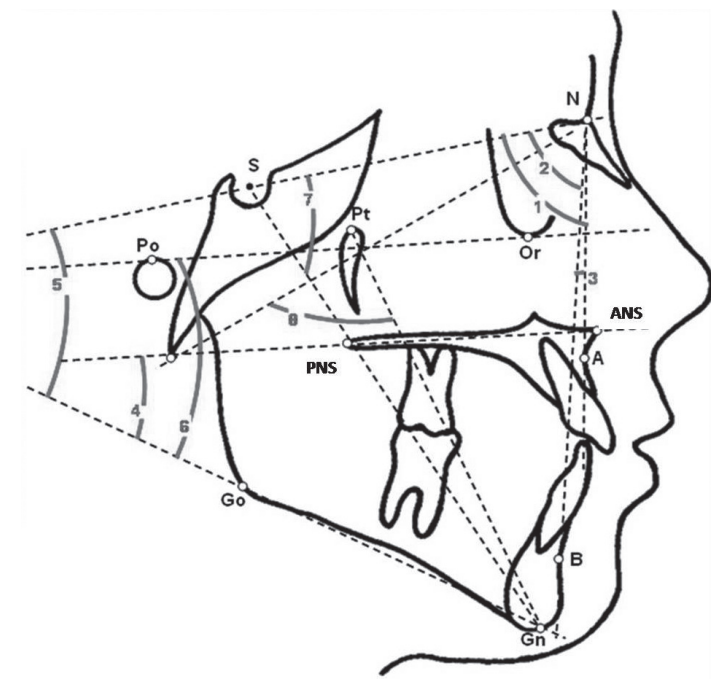

Figure 2. Angular cephalometric variables: (1) SNA angle; (2) SNB angle; (3) ANB angle; (4) PP.GoGn angle; (5) SN.GoGn angle; (6) FMA angle; (7) SN.Gn angle; (8) BaN.PtGn angle. mid-palatal suture, and the appliance was removed. Afterwards, the patients used a removable retention for a mean period of 6.3 months (range: 5.4 to 7.1 months).

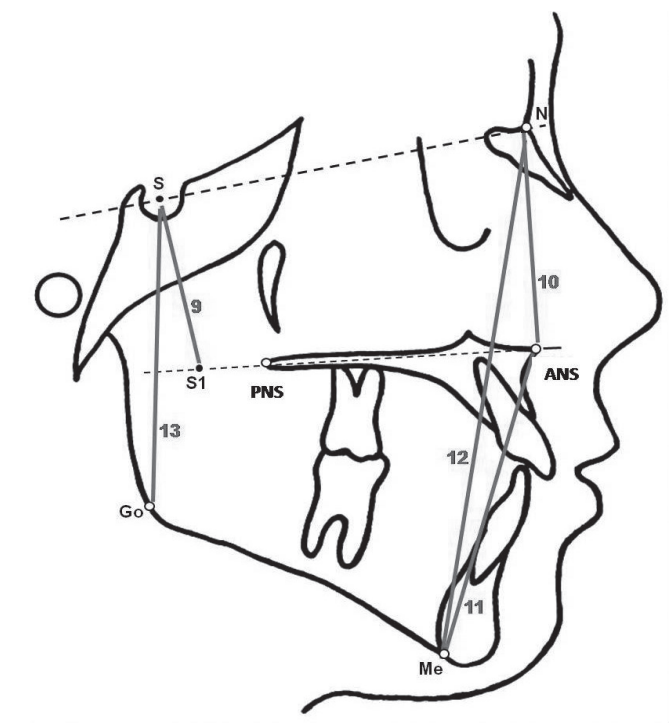

Figure 3. Linear cephalometric variables: (9) S-S1; (10) N-ANS; (11) ANS-Me; (12) N-Me; (13) S-Go.

Table 1. Description of cephalometric measures evaluated in the present study.

\begin{tabular}{|c|c|}
\hline Measure & Description \\
\hline \multicolumn{2}{|l|}{ Sagittal } \\
\hline SNA $\left({ }^{\circ}\right)$ & Measures the position of the maxilla in relation to the anterior base of the skull \\
\hline $\mathrm{SNB}\left({ }^{\circ}\right)$ & Measures the position of the mandible in relation to the anterior base of the skull \\
\hline $\operatorname{ANB}\left({ }^{\circ}\right)$ & $\begin{array}{l}\text { Determined by the difference between the SNA and SNB angles. Measures the sagittal position between } \\
\text { maxilla and mandible }\end{array}$ \\
\hline \multicolumn{2}{|l|}{ Vertical } \\
\hline $\mathrm{S}-\mathrm{S} 1(\mathrm{~mm})$ & $\begin{array}{l}\text { Linear measure determined by the union of S (sela) and S1(connecting point of the perpendicular line } \\
\text { relative to the SN line, traced from the S point, with the palatal plane) points. Measures the facial posterior } \\
\text { superior height }\end{array}$ \\
\hline SN.GoGn $\left({ }^{\circ}\right)$ & Expresses the inclination of the mandible in relation to the anterior base of the skull \\
\hline FMA $\left({ }^{\circ}\right)$ & Expresses the inclination of the mandible in relation to Frankfurt's horizontal plane \\
\hline PP.GoGn $\left(^{\circ}\right)$ & Expresses the inclination of the mandible in relation to the palatal plane \\
\hline SN.Gn $\left({ }^{\circ}\right)$ & Expresses the direction of the mandibular growth \\
\hline BaN.PtGn $\left({ }^{\circ}\right)$ & Expresses the direction of the mandibular growth \\
\hline N-NAS (mm) & Expresses the anterior superior height of the face \\
\hline S-Go $(\mathrm{mm})$ & Expresses the posterior height of the face \\
\hline NAS-Me (mm) & Expresses the anterior inferior height of the face \\
\hline $\mathrm{N}-\mathrm{Me}(\mathrm{mm})$ & Expresses the anterior height of the face \\
\hline $\mathrm{S}-\mathrm{Go} / \mathrm{N}-\mathrm{Me}(\%)$ & Ratio between the posterior (S-Go) and the anterior (N-Me) height of the face, multiplied by 100 \\
\hline
\end{tabular}




\section{Cephalometry}

Standardized lateral cephalometric radiographs were obtaiend from all patients before the beginning of the treatment (T1) and after the use of the removable retention (T2). The mean interval between the radiographs was 12.2 months (range: 16.2 to 9.6 months).

The cephalometric outlines were traced manually by the same experienced and calibrated examiner. The measurement fractions were approximated for whole numbers or for every $0.5^{\circ}$ or $0.5 \mathrm{~mm}$. By using lateral cephalograms, the following was analyzed: 1) Direction of the maxillary dislocation and the alterations in posterior, anterior superior, inferior and total facial height; 2) Alterations in the facial pattern, growth direction and/or mandibular inclination; 3) Sagittal alterations of the maxilla and the mandible.

The cephalometric measures used in the present study are summarized in Figures 2 and 3 and Table 1.

\section{Statistical Analysis}

Cephalometric data were subjected to statistical analysis using the SPSS software, v. 15.0 (SPSS Inc.,

Table 2. Method error (ME) for the cephalometric measures assessed on repeated measurements of 10 subjects. $(M E)=$ $\sqrt{ } \Sigma\left(x_{1}-x_{2}\right)^{2} / 2 n$.

\begin{tabular}{lll}
\hline Measure & ME & p values \\
\hline Sagittal & & \\
SNA $\left(^{\circ}\right)$ & 0.90 & 0.14 \\
SNB $\left(^{\circ}\right)$ & 0.00 & 1.00 \\
ANB $\left(^{\circ}\right)$ & 0.90 & 0.09 \\
Vertical & & \\
S-S1 (mm) & 0.20 & 0.68 \\
SN.GoGn $\left(^{\circ}\right)$ & 0.80 & 0.34 \\
FMA $\left({ }^{\circ}\right)$ & 0.40 & 0.62 \\
PP.GoGn $\left(^{\circ}\right)$ & 0.20 & 0.70 \\
SN.Gn $\left({ }^{\circ}\right)$ & 0.05 & 0.59 \\
BaN.PtGn $\left({ }^{\circ}\right)$ & 0.05 & 0.67 \\
N-NAS (mm) & 0.45 & 0.08 \\
S-Go (mm) & 0.00 & 1.00 \\
NAS-Me (mm) & 0.20 & 0.16 \\
N-Me (mm) & 0.80 & 0.06 \\
S-Go/N-Me ( $\%)$ & 0.00 & 1.00 \\
\hline
\end{tabular}

Chicago, IL, USA). Shapiro-Wilkes test was used to verify data distribution. Paired t-test was used to compare the pre- and post-treatment values. The changes were considered statistically significant for $\mathrm{p}<0.05$.

Ten radiographs from 10 randomly selected patients were re-traced to obtain the method error, after a minimal interval of 3 months. Dahlberg's formula (12) was applied to estimate the order of magnitude of errors and the paired " $t$ " test was used to detect its statistical significance. None of the analyzed variables had a statistically significant error $(\mathrm{p}<0.05)$, and no variable showed an error greater than $1 \mathrm{~mm}$ or $1^{\circ}$ (Table 2).

\section{RESULTS}

The values (means and standard deviations) of each cephalometric variable measured at the beginning (T1) and at the end (T2) of the treatment are shown in Table 3. The means, standard deviations, variation of the difference between $\mathrm{T} 1$ and $\mathrm{T} 2$ values and the statistical significance ("p" values) are also found in Table 3.

A statistically significant difference between $\mathrm{T} 1$ and T2 was observed in S-S1 $(\mathrm{p}<0.05)$, N-NAS $(\mathrm{p}<0.01)$, S-Go $(p<0.01)$, NAS-Me $(p<0.05)$ and N-Me $(p<0.01)$.

\section{DISCUSSION}

In the present study, the inferior dislocation of the maxilla was verified with the increase of the S-S1 distance $(0.80 \mathrm{~mm})$ and N-ANS $(1.55 \mathrm{~mm})$, which occurred in a statistically significant manner $(\mathrm{p}<0.05)$. The increased ANS-Me $(0.59 \mathrm{~mm})$ and N-Me $(2.65$ $\mathrm{mm}$ ) measurements was significant, indicating that the superior anterior, inferior anterior and total height of the face increased after RME and the use of the removable retention. The posterior height of the face (S-Go) also increased significantly $(1.50 \mathrm{~mm})$. The inferior dislocation of the maxilla was also found in other studies $(3,5,8,9,13,14)$ that used banded and bonded appliances, showing that bonded appliance is not able to completely control vertical displacement after RME. However, some authors believe that the vertical dislocation of the maxilla with bonded RME appliance appears to be lower than that with banded appliances $(8,9)$.

The increase of the anterior $(\mathrm{N}-\mathrm{Me})$ and posterior (S-Go) heights of the face was proportional, not altering the facial pattern by the $\mathrm{S}-\mathrm{Go} / \mathrm{N}-\mathrm{Me}$ ration. The direction of the mandibular growth (BaN.PtGn and NS.GN) was also constant. The inclination of the mandible did not 
increase in relation to Frankfurt's horizontal plane, anterior base of the skull or palatal plane (verified by the FMA, SN.GoGn and PP.GoGn angles), showing that the mandible did not rotate clockwise and justifying the alteration of the ANB angle as well.

This way, in view of the absence of alterations in the related measurements regarding the facial standard (SN.GoGn, FMA, SN.Gn, BaN.PtGn and S-Go/N-Me), RME with the bonded maxillary expansion appliance does not cause damaging vertical alterations. These findings corroborate the results of other studies that also evaluated longitudinally the vertical effects associated with the RME $(13,15,16)$, although in those cases the RME was followed by other orthodontic therapy.

Possible vertical alterations caused by maxillary expansion $(3-5,9,14,17)$ can be reduced in the long term, when overcorrection, extrusion and flaring of the molars, which can be associated with the clockwise rotation of the mandible, are not present any longer. Still, such alterations may not resist to the normal growth pattern of the patient above 6 months after RME appliance removal, as observed in the present study.

Literature does not present a consensus regarding the sagittal alterations associated with the RME (1). The anterior dislocation of the maxilla, associated with the use of conventional expansion appliances and bonded maxillary expansion appliances was verified by several authors $(3-5,14,18)$. However, the dislocation of the maxilla can also occur in the posterior direction $(8,9)$.

In the present study, it was verified the RME with the bonded maxillary expansion appliance did not promote significant sagittal alterations in the maxilla and the mandible or in the relation between the maxilla and the mandible after 6 months of use of a removable retention. Sarver and Jhonston (9) verified that the anterior dislocation of the maxilla is greater with the use of a banded appliance, suggesting the use of bonded maxillary expansion appliances to restrict the anterior movement of the mandible, which is not desirable in patients with class II malocclusions.

Haas (3) reported the anterior dislocation of the maxilla after RME, favoring the correction of class III malocclusions and anterior crossbite. However, Hass (4) also verified that the values tend to drop to near the initial values after the retention period. The recurrence of the sagittal cephalometric alterations after RME using Haas'

Table 3. Mean and standard deviation (SD) before (T1) and after treatment (T2) and the differences between T1 and T2.

\begin{tabular}{|c|c|c|c|c|c|c|c|c|}
\hline \multirow{2}{*}{ Measure } & \multicolumn{2}{|c|}{$\mathrm{T} 1$} & \multicolumn{2}{|c|}{$\mathrm{T} 2$} & \multicolumn{3}{|c|}{$\mathrm{T} 2-\mathrm{T} 1$} & \multirow{2}{*}{$\frac{\text { Paired } t-\text { tes }}{p \text { value }}$} \\
\hline & Mean & $\mathrm{SD}$ & Mean & $\mathrm{SD}$ & Mean & SD & Range & \\
\hline \multicolumn{9}{|l|}{ Sagittal } \\
\hline SNA $\left({ }^{\circ}\right)$ & 80.42 & 4.54 & 79.96 & 3.93 & -0.46 & 1.73 & -1.16 to 0.24 & 0.18 \\
\hline SNB $\left({ }^{\circ}\right)$ & 76.88 & 4.99 & 76.73 & 4.71 & -0.15 & 1.61 & -0.80 to 0.49 & 0.63 \\
\hline ANB $\left({ }^{\circ}\right)$ & 3.53 & 2.43 & 3.23 & 2.86 & -0.30 & 1.25 & -0.81 to 0.20 & 0.22 \\
\hline \multicolumn{9}{|l|}{ Vertical } \\
\hline $\mathrm{S}-\mathrm{S} 1(\mathrm{~mm})$ & 36.75 & 3.02 & 37.55 & 2.92 & 0.80 & 1.69 & 0.12 to 1.49 & $0.02 * *$ \\
\hline SN.GoGn $\left({ }^{\circ}\right)$ & 37.40 & 5.82 & 37.59 & 5.49 & 0.19 & 2.00 & -0.61 to 1.00 & 0.62 \\
\hline FMA $\left({ }^{\circ}\right)$ & 30.96 & 5.04 & 30.78 & 5.00 & -0.18 & 1.64 & -0.85 to 0.49 & 0.58 \\
\hline PP.GoGn $\left({ }^{\circ}\right)$ & 29.36 & 4.65 & 29.09 & 4.56 & -0.26 & 2.26 & -1.18 to 0.64 & 0.55 \\
\hline SN.Gn $\left({ }^{\circ}\right)$ & 69.25 & 4.76 & 69.78 & 4.50 & 0.53 & 1.63 & -0.12 to 1.19 & 0.10 \\
\hline BaN.PtGn $\left({ }^{\circ}\right)$ & 85.11 & 3.74 & 84.86 & 3.95 & -0.25 & 1.88 & -1.01 to 0.51 & 0.50 \\
\hline N-NAS (mm) & 45.76 & 2.95 & 47.32 & 4.01 & 1.55 & 1.86 & 0.8 to 4.2 & $0.00 *$ \\
\hline S-Go (mm) & 64.53 & 5.11 & 66.03 & 5.69 & 1.50 & 2.35 & 0.54 to 2.45 & $0.00^{*}$ \\
\hline NAS-Me (mm) & 63.19 & 4.25 & 63.78 & 4.62 & 0.59 & 1.40 & 0.0 to 1.16 & $0.04 * *$ \\
\hline $\mathrm{N}-\mathrm{Me}(\mathrm{mm})$ & 106.42 & 5.04 & 109.07 & 6.73 & 2.65 & 2.23 & 0.44 to 2.25 & $0.00^{*}$ \\
\hline S-Go/N-Me (\%) & 60.71 & 4.91 & 60.57 & 4.20 & -0.13 & 2.14 & -1.00 to 0.72 & 0.74 \\
\hline
\end{tabular}

$* * \mathrm{p}<0.05, * \mathrm{p}<0.01$ (Paired $t$-test). 
appliance was also verified with the use of Hyrax and the bonded maxillary expansion appliances $(5,10,15)$.

The maxilla protrudes in the anterior direction as an immediate response to the therapy. However, during the retention period, it tends to return to its initial position, thus explaining the divergence of the results. The anterior dislocation of the maxilla can be observed when the cephalometric analysis is performed in the short term, immediately after the active phase of RME or after the use of a fixed retention $(3,4,14,17,18)$. However, when long-term evaluations are performed, after corrective orthodontic treatment or use of removable retentions, the sagittal alterations are not significant $(13,15,16)$, as verified in the present study.

Considering the specific conditions of this research, it may be concluded that RME with the acrylic bonded maxillary expansion appliances did not promote deleterious vertical or sagittal cephalometric alterations. Thus, the bonded maxillary expansion appliance could be a viable option for the correction of maxillary narrowing, regardless of the patient's vertical problems or facial patter. The maxilla displaced downward but it did not modify the facial growth patterns or the direction of the mandible growth. The vertical changes found with use of the bonded appliance were small and probably transitory, similar to the use of banded expansion appliances, and a longer follow up study might elucidate whether their were temporary or permanent.

\section{RESUMO}

Os aparelhos disjuntores com cobertura oclusal de acrílico têm sido sugeridos para controlar o aumento da dimensão vertical da face após a expansão rápida da maxila (ERM). Entretanto, ainda não há consenso na literatura sobre seu real efeito esquelético. $\mathrm{O}$ objetivo desse estudo prospectivo foi avaliar longitudinalmente as alterações esqueléticas verticais e sagitais após a ERM realizada com o aparelho disjuntor com cobertura oclusal. A amostra consistiu de 26 crianças, com idade média de 8,7 anos (variação: 6.9-10,9 anos), apresentando mordida cruzada posterior esquelética e indicação para ERM. Após a expansão maxilar, o aparelho foi utilizado como contenção fixa por 3,4 meses, sendo posteriormente substituído por uma contenção removível. O estudo cefalométrico foi realizado em telerradiografias laterais tomadas antes do início do tratamento e novamente 6,3 meses após a remoção do disjuntor. A comparação intragrupo foi feita utilizando-se o teste $\mathrm{t}$ pareado. Os resultados mostraram que não houve alterações esqueléticas sagitais significantes ao fim do tratamento. Houve um pequeno aumento em cinco das onze medidas cefalométricas verticais analisadas. A maxila se moveu inferiormente, porém não modificou o padrão de crescimento facial, a inclinação ou direção de crescimento mandibular. Considerando-se as condições específicas deste trabalho, podese concluir que a ERM realizada com o aparelho disjuntor com cobertura oclusal de acrílico não promoveu alterações esqueléticas verticais ou sagitais prejudiciais. As alterações verticais encontradas com o uso do aparelho colado foram pequenas e provavelmente transitórias, similar ao que ocorre com o uso dos aparelhos expansores bandados.

\section{REFERENCES}

1. De Rossi M, Gaviao MBD. Posterior crossbite: Diagnostic and early treatment. Stoma 2008;87:18-31.

2. Ballanti F, Lione R, Fanucci E, Franchi L, Baccetti T, Cozza P. Immediate and post-retention effects of rapid maxillary expansion investigated by computed tomography in growing patients. Angle Orthodontist 2009;79:24-29.

3. Haas AJ. Rapid expansion of the maxillary dental arch and nasal cavity by opening the midpalatal suture. Angle Ortho 1961;31:73-79.

4. Haas AJ. The treatment of maxillary deficiency by opening the midpalatal suture. Angle Ortho 1965;35:200-217.

5. Werts RA. Skeletal and dental changes accompanying rapid midpalatal sutura opening. Am J Ortho 1970;58:41-66.

6. Cohen M, Silverman E. A new and simple palate splitting device. J Clin Orthod 1973;7:368-369.

7. Mc Namara Jr, JA, Brudon WL. Bonded rapid maxillary expansion appliance. In: Orthodontic and orthopedic treatment in the mixed dentition. Mc Namara Jr, JA, Brudon WL. 5th ed. Ann Arbor: Needham Press; 1995. p. 145-169.

8. Sarver DM, Johnston MW. Skeletal changes in vertical and anterior displacement of the maxilla with bonded rapid palatal expansion appliances. Am J Orthod Dentofacial Orthop 1989;95:462-466.

9. Asanza S, Cisneros GJ, Nieberg LG. Comparison of Hyrax and bonded expansion appliances. Angle Orthod 1997;67:15-22.

10. Lagravere MO, Major PW, Flores-Mir C. Long-term skeletal changes with rapid maxillary expansion: a systematic review. Angle Orthod 2005;75:1046-1052.

11. De Rossi M, Rocha RSS, Gavião MBD. Effects of bonded rapid maxillary expansion appliance (BRMEA) in vertical and sagittal dimensions: a systematic review. Braz J Oral Sci 2008;7:1571-1574

12. Houston WJB. The analysis of errors in orthodontic measurements. Am J Orthod Dentofacial Orthop 1983;83:382-390.

13. Chang JY, Mc Namara JA Jr, Herberger TA. A longitudinal study of skeletal side effects induced by rapid maxillary expansion. Am J Orthod Dentofac Orthop 1997;112: 330-337.

14. Chung $\mathrm{CH}$, Font B. Skeletal and dental changes in the sagittal, vertical, and transverse dimensions after rapid palatal expansion. Am J Orthod Dentofac Orthop 2004;126:569-575.

15. Reed N, Ghosh J, Nanda RS. Comparison of treatment outcomes with banded and bonded rapid palatal expansion appliances. Am J Orthod Dentofacial Orthop 1999;116:31-40.

16. Garib DG, Henriques JF, Carvalho PE, Gomes SC. Longitudinal effects of rapid maxillary expansion. Angle Orthod 2007;77:442-448.

17. Basciftci FA, Karaman AI. Effects of a modified acrylic bonded rapid maxillary expansion appliance and vertical chin cap on dentofacial structures. Angle Orthod 2002;72:61-71.

18. Ramoglu SI, Sari Z. Maxillary expansion in the mixed dentition: rapid or semi-rapid? Eur J Orthod 2010;32:11-18.

19. Farronato G, Giannini L, Galbiati G, Maspero C. Sagittal and vertical effects of rapid maxillary expansion in Class I, II, and III occlusions. Angle Orthod 2011;81:298-303.

Received October 10, 2010 Accepted April 6, 2011 